\title{
STRUČNI SURADNICI U GLAZBENIM ŠKOLAMA U REPUBLICI HRVATSKOJ
}

\author{
Marina Sokol \\ Glazbena škola u Varaždinu, Republika Hrvatska
}

\begin{abstract}
Sažetak
Predmet je istraživanja broj zaposlenih stručnih suradnika na neodređeno radno vrijeme u glazbenim osnovnim i srednjim školama u Republici Hrvatskoj. $U$ istraživanju je sudjelovalo 38 ravnatelja glazbenih škola, od sveukupnog broja od 52 samostalne glazbene osnovne i srednje škole. Ispitivan je postojeći broj zaposlenih stručnih suradnika u glazbenim školama, profil stručnog suradnika koji je zaposlen u glazbenoj školi te subjektivna procjena ravnatelja postoji li potreba zapošljavanja stručnih suradnika u glazbenim školama. Rezultati upućuju na zaključak kako je u glazbenim školama zaposlen zanemariv postotak stručnih suradnika, a procjena ravnatelja upućuje na činjenicu kako postoji velika potreba za različitim profilima stručnih suradnika u glazbenim školama bez obzira radi li se o osnovnoj ili srednjoj glazbenoj školi. Izrazito je važno napomenuti kako se ravnatelji, stručni suradnici, odnosno odgojno-obrazovni djelatnici te učenici i roditelji ne smiju zadovoljiti postojećim stanjem bez obzira na trenutnu situaciju. Cilj je provedenog istraživanja potaknuti više obrazovne instance na akciju zapošljavanja stručnih suradnika u glazbenim školama u svrhu unapređenja odgojno-obrazovnog procesa, pružanja pomoći i podrške učenicima u glazbenim osnovnim i srednjim školama, uvažavanja odredbi Državnog pedagoškog standarda te potpunog iskorjenjivanja diskriminacije koja se vrši naspram glazbenih škola u području zapošljavanja stručnih suradnika na neodređeno radno vrijeme.
\end{abstract}

Ključni pojmovi: umjetnička škola, glazbena škola, stručni suradnik, pedagog, psiholog, stručnjak edukacijsko-rehabilitacijskog profila, knjižničar

\section{UvoD}

Stručne suradnike možemo promatrati kao ključne nositelje razvojno-pedagoške djelatnosti odgojno-obrazovne ustanove, a u suvremenoj školi 21. stoljeća odgoj i obrazovanje djece i mladih velikim dijelom ovisi o visoko motiviranim i kompetentnim stručnjacima (Bizjak Igrec, Galić i Fajdetić, 2014). U suvremenu školu 21. stoljeća možemo ubrojiti i umjetničke odnosno glazbene škole, no postavlja se pitanje ostvaruju li glazbene škole svoj maksimalni potencijal te imaju li učenici glazbenih škola jednake uvjete za razvoj kao i njihovi vršnjaci u školama drugih obrazovnih profila s obzirom na broj stručnih suradnika svih profila.

Prema Bizjak Igrec, Galić i Fajdetić (2014) stručni suradnik svojim radom i obnašanjem svoje dužnosti pridonosi kvaliteti odgojno-obrazovnog procesa te afirmaciji ugleda ustanove. Također, partnerski surađuje sa svim subjektima procesa odgoja i obrazovanja, a svoj rad s učenicima temelji na potpunom uvažavanju djetetove osobnosti i poticanju njegova razvoja. $S$ roditeljima ostvaruje savjetodavni odnos sa svrhom poštivanja načela dobrobiti učenika. Stručni suradnik djeluje kao osoba koja potiče kreativnost i inicijativu kolega učitelja i nastavnika, poštuje njihovu stručnost, a svoja znanja i vještine dijeli sa svim sudionicima odgojno-obrazovnog procesa. 
Cilj je provedenog istraživanja bio utvrditi broj stručnih suradnika u umjetničkim, odnosno glazbenim školama, tj. željelo se utvrditi postoji li razlika između tzv. isključivo općeobrazovnih osnovnih i srednjih škola i glazbenih škola u pogledu broja stručnih suradnika. S obzirom na široko područje rada stručnih suradnika svih profila možemo tvrditi kako je njihova uloga u radu i životu škole izrazito važna, a ovim se istraživanjem željelo utvrditi stvarno brojčano stanje stručnih suradnika te ukazati na potrebu zapošljavanja stručnih suradnika u glazbenim školama ponajprije zbog pružanja istih uvjeta školovanja i obrazovanja djece i mladih.

\section{ZAKONSKE ODREDNICE I PRAVILNICI}

U osnovnim i srednjim školama Republike Hrvatske zaposleni su i rade različiti profili stručnih suradnika. Prema Pravilniku o tjednim radnim obvezama učitelja i stručnih suradnika u osnovnoj školi „stručni suradnici u osnovnoj školi su: pedagog, psiholog, stručnjak edukacijsko -rehabilitacijskog profila i knjižničar, a obavljaju neposredan odgojno-obrazovni rad s učenicima te stručno-razvojne i koordinacijske poslove. Prema istom pravilniku, „stručni suradnici obavljaju neposredan odgojno-obrazovni rad s učenicima, stručno-razvojne i druge stručne poslove u skladu sa zahtjevima struke te ostale poslove koji proizlaze iz neposrednog odgojno-obrazovnog rada ili drugih zakona."

Prema Pravilniku o tjednim radnim obvezama učitelja i stručnih suradnika u osnovnoj školi stručni suradnik pedagog „planira i programira rad, priprema se i obavlja poslove u pedagoškom radu, analizira i vrednuje djelotvornost odgojno-obrazovnog rada škole i sudjeluje u analizi rezultata odgojno-obrazovnog procesa, sudjeluje u izradi godišnjeg plana i programa rada škole i školskog kurikuluma, savjetuje i pomaže u radu učiteljima, drugim stručnim suradnicima i roditeljima, sudjeluje u izricanju pedagoških mjera, predlaže mjere za poboljšanje, sudjeluje u radu povjerenstva za upis djece u osnovnu školu i prvostupanjskog povjerenstva za utvrđivanje psihofizičkog stanja djeteta, identificira i prati učenike s posebnim odgojno-obrazovnim potrebama, izrađuje i provodi preventivne programe, vodi odgovarajuću pedagošku dokumentaciju, surađuje s ustanovama, stručno se usavršava te obavlja druge poslove unapređivanju i razvoju odgojno-obrazovne djelatnosti škole."

Prema članku 11. Državnog pedagoškog standarda srednjoškolskog sustava odgoja $i$ obrazovanja škola koja upisuje do 180 učenika zapošljava dva stručna suradnika od kojih jedan mora biti pedagog, dok škola s više od 180 a manje od 500 učenika zapošljava tri stručna suradnika sukladno vrstama i opsegu programa koje izvodi. Također, $u$ istom se članku navedenog pravilnika ističe kako škola koja ima više od 500 učenika zapošljava četiri stručna suradnika.

\section{Metoda}

Cilj je istraživanja utvrditi broj stručnih suradnika u umjetničkim, odnosno glazbenim školama, tj. željelo se utvrditi postoji li razlika između tzv. isključivo općeobrazovnih škola i glazbenih škola u pogledu broja stručnih suradnika.

Informacije su prikupljene anketnim upitnikom koji je poslan svim glazbenim školama u Republici Hrvatskoj s preporukom da anketni upitnik ispunjavaju isključivo ravnatelji navedenih škola. Prema Popisu državnih umjetničkih škola koji je dostupan na stranici Ministarstva znanosti i obrazovanja postoji sveukupno 101 umjetnička škola. Od 101 umjetničke škole broj samostalnih glazbenih škola, odnosno glazbenih škola koje nisu u sastavu osnovne ili srednje škole, iznosi 52. Anketni je upitnik bio dostupan na Google obrascu u razdoblju od 20. siječnja do 20. travnja 2019. godine te je poslan na adrese 52 glazbene škole s preporukom da ga isključivo ispunjava ravnatelj. Njih 38 ravnatelja glazbenih škola odgovorilo je na anketni upitnik 
iz čega možemo zaključiti kako uzorak ispitanika iznosi 38 , odnosno $73,1 \%$ od ukupnog broja glazbenih škola.

\section{Instrument istraživanja}

Instrument je istraživanja anketa koja se sastoji od tri pitanja: postoji li uopće stručni suradnik u glazbenoj školi, koji je profil stručnog suradnika koji je zaposlen (ako je zaposlen) te postoji li potreba za zapošljavanjem stručnih suradnika u glazbenim školama prema mišljenju ravnatelja kao poslovodnog i stručnog voditelja škole.

\section{REZULTATI I RASPRAVA}

Prvo pitanje odnosilo se na trenutnu situaciju u glazbenim školama u Republici Hrvatskoj odnosno postoji li stručni suradnik (pedagog, psiholog, socijalni pedagog, logoped, defektolog i/ili knjižničar) zaposlen na neodređeno radno vrijeme. Njih 72,2 \% ispitanika odgovorilo je kako u njihovoj školi ne postoji zaposlen stručni suradnik, dok je $27,8 \%$ ispitanika odgovorilo kako u njihovoj školi postoji zaposlen stručni suradnik na neodređeno radno vrijeme.

Drugo pitanje odnosilo se na profil stručnog suradnika koji je zaposlen u glazbenoj školi. Sukladno dobivenim podacima vidljivo je kako je u glazbenim školama zaposleno:

- 5 knjižničara odnosno $13,9 \%$

- 4 pedagoga odnosno $11,1 \%$

- 3 psihologa odnosno 8,3\%.

Njih 26 ispitanika, odnosno 72,2 \%, odgovorilo je kako nemaju zaposlenog stručnog suradnika u školi.

Treće pitanje odnosilo se na mišljenje odnosno subjektivnu procjenu ravnatelja kao poslovodnog i stručnog voditelja odgojno-obrazovne ustanove postoji li uopće potreba za zapošljavanjem stručnih suradnika u glazbenim školama. Naedeno je pitanje otvorenog tipa na koje su ispitanici mogli dati odgovor iako odgovor nije bio obavezan. Na pitanje je odgovorio 31 ispitanik, a mišljenja se razlikuju: jedan je ispitanik odgovorio „ne znam“, jedan je ispitanik odgovorio „stručni suradnici nisu potrebni u glazbenim školama“ dok je 29 ispitanika odgovorilo pozitivno, odnosno njihovo je mišljenje kako je stručni suradnik potreban u radu glazbenih škola.

Govoreći o potrebi zapošljavanja stručnih suradnika u glazbenim školama, ispitanici su odgovorili sljedeće:

- „Glazbene škole dio su sustava obrazovanja, kao i sve ostale škole u RH. Smatram da je stanje po pitanju zapošljavanja stručnih suradnika u glazbenim i plesnim školama sramotno i neustavno. Glazbene škole se stavljaju u neravnopravan položaj u odnosu na sve ostale škole. Priča je kako glazbene i plesne škole nisu obvezatne, ali ni strukovne i ostale srednje škole i fakulteti nisu obavezni, ali su ipak ekipirani prema standardima zanimanja. Škola koja nema stručnog suradnika ne može svojim učenicima pružiti kvalitetno obrazovanje i teret poslova koje obavlja pedagog škole pada na nestručne osobe, uglavnom ravnatelje."

- „Više no potrebno. Mnogo ambicioznih roditelja, djece pod pritiscima nagrađivanja, natjecanja, ocjena, izvrsnosti, a glazbena naobrazba donosi i druge kvalitete koje roditelj ili javnost dovoljno ne vrednuje i cijeni. Da, potreban nam je stručni suradnik psiholog za radionice i rad s djecom izloženu stresom i nerealnim očekivanjima roditelja, da amortizira odnose učitelja i roditelja, pritiske nastavnika u radu. Pedagog jer je sve više birokracije koja je u neskladu s praksom u umjetničkim školama." 
- „Svakako. Stručni suradnici čine tim koji je od velike pomoći ravnatelju. Tajnici su pravna podrška, računovođe financijska, a stručni suradnici pokrivaju sve što se tiče učenika $i$ roditelja. Na žalost, ravnatelji u glazbenim školama su najčešće prepušteni 'sebi samima' i samo zahvaljujući svojim sposobnosti, snalažljivosti i kreativnosti 'plivaju' u moru problema."

- „Naravno da su potrebni jer se susrećemo s problematikom za koju nismo educirani, a roditelji nas ne upoznaju s istom. Naime, mi uočimo neke pojavnosti kod djeteta, a ne znamo o čemu se radi niti kako pristupiti takvom djetetu. Roditelji smatraju, većinom, da nama u glazbenoj ne treba povjeriti takve podatke koje znaju učitelji i stručni suradnici u općeobrazovnoj školi. Tako da, da, trebamo barem na pola radnog vremena u manjim školama, možda najbolje defektologa, ako ne i psihologa."

- „Da. Naša škola ima 580 učenika, a nemamo pedagoga."

- "Da."

- "Stručni suradnik je potreban u glazbenim školama, kao i u svim drugim školama, zbog podizanja kvalitete nastave, pomoći u radu s učenicima, nastavnicima, roditeljima, pomoći u pripremama za javne nastupe učenika... Kroz projekt mjere pripravništva MZO i HZZ od 12. mjeseca imamo pripravnicu pedagoginju na određeno-godinu dana i već sad vidimo koliko će nam dobro doći njezina pomoć u raznim situacijama."

- „Učenici koji pohađaju glazbenu gimnaziju i nastavu općeobrazovnih predmeta koja im je osigurana u samoj glazbenoj školi - takve škole MORAJU imati i stručne suradnike."

- „Da. Zbog potreba provođenja postupaka, kako s posebno darovitima, tako i s onim učenicima koji iz raznih razloga teže udovoljavaju posebnim zahtjevima koje pred njih postavlja školovanje u umjetničkim programima te naročito zbog učestale izloženosti učenika povećanome stresu povezanim s javnim nastupima te ispitima pred povjerenstvima koji su u umjetničkim školama pravilo, a ne, kao u drugim obrazovnim programima, izuzetak. Pridodajmo tome i, za ogromnu većinu učenika prisutno, povećano opterećenje koje proizlazi iz paralelnog pohađanja umjetničkog i nekog drugog obrazovnog programa."

- „Apsolutno. Nepostojanjem stručnih suradnika u glazbenim školama sve konflikte i potencijalno agresivne situacije, bilo da se radi o kolegama, učenicima ili roditeljima, rješava ravnatelj koji definitivno nije kompetentna osoba za obavljanje takvih poslova."

- „Da, nedostatkom stručnih suradnika nije moguće obavljati neke od redovnih poslova za koje je zakonodavac predvidio sudjelovanje stručnih suradnika."

- „Da, stručni suradnici svakako su potrebni u umjetničkim školama. Uzevši u obzir da je nastava u umjetničkim školama specifična te da se svaki nastup učenika temelji na individualnom pristupu učeniku, najčešća problematika (naročito u glazbenim školama) je na koji način učeniku pružiti psihološku potporu u uspješnom ostvarivanju javnog nastupa, kako ga pripremiti na uspjeh, ali i na neuspjeh, čime motivirati učenika za permanentno vježbanje instrumenta i sl. Važno je napomenuti da učenici najčešće moraju ostvariti javni nastup za vrlo veliki auditorij (poznat ili nepoznat) u poznatom i nepoznatom okruženju, a nastupi na audicijama za natjecanja i samim natjecanjima stvaraju dodatni pritisak na učenika, ali i na mentora, što zasigurno nije lako ako uzmemo u obzir da je dob učenika u osnovnoj glazbenoj ili plesnoj školi od 7 godina i više. Svakako, posebna se problematika javlja u srednjim glazbenim i plesnim školama gdje je samo gradivo koje učenici moraju svladati tijekom školovanja sve zahtjevnije, vremensko razdoblje za pripremu javnih nastupa duži i složeniji, a sama dob učenika nalaže sve kompleksniji psihološki i pedagoški pristup mentora."

- „Da. Nužni su, ne samo zbog administrativnih poslova, već zbog rada s učenicima koji mogu više, talentiranih i nadarenih te zbog savjetovanja učenika i roditelja." 
Marina Sokol

STRUČNI SURADNICI U GLAZBENIM ŠKOLAMA U REPUBLICI...

- „Da, svakako. Ravnatelji glazbenih škola često se bave stvarima za koje nisu stručni u nedostatku suradnika, a i talentirani učenici imaju svoje potrebe za stručnom službom."

- „Mislim da je umjetničkim, pogotovo malim, osnovnim školama, kao što je naša, nisu baš neophodni stručni suradnici, ali isto tako kad se pojavi neki problem, dobro bi došli. $U$ naše škole ipak se upisuju djeca dobrovoljno i voljna su učiti i sudjelovati u nečem lijepom i na kraju nečem što ih oplemenjuje i produhovljuje pogotovo ako imaju 'normalne', a ne bolesno ambiciozne roditelje i nastavnike!"

- „Da, potrebni su u svrhu bavljenja učenicima za one djelatnosti koju psiholozi i pedagozi imaju u svojoj nadležnosti."

- „Da, zbog specifičnosti umjetničke struke i pomoći darovitoj djeci te njihovim učiteljima."

- „Da."

- „Da. Vrlo često dolazi do potrebe, dijelom i zbog nastavnika određenih predmeta kao i zbog odnosa učenika prema nastavi."

- „Da. Nastavnici i ravnatelji često nisu dovoljno educirani za rad s djecom s problemima u učenju, u obitelji, zdravstvenim poteškoćama itd."

- „Da."

- „Mislim da su potrebni zato što, kad postoji neki problem s djetetom, nemamo ga kamo uputiti. Mislim da je potrebno isto kao i u osnovnim školama."

- „S obzirom da smo dobili pravo na zapošljavanje stručnog suradnika pedagoga kroz mjeru MZO-a, uvidjeli smo da se takvom stručnom osobom uvelike može unaprijediti rad umjetničkih škola."

- "Naravno da su potrebni, pogotovo psiholog zbog stresnosti posla, kako za učenike (nastupi, natjecanja i sl.) tako i za nastavnike a i ravnatelje."

- „Da, pomogao bi u rješavanju situacija s djecom s poteškoćama."

- „Apsolutno postoji potreba jer smo mi škola kao i svaka druga škola i potreban je stručni suradnik."

- „Ako se radi samo o osnovnim glazbenim školama s relativno malim brojem učenika (do oko 200), smatram da ne trebaju stručni suradnici. Za glazbene škole koje u vertikali imaju srednje obrazovanje svakako trebaju, a posebno knjižničar i zatim netko iz pedagoške ili psihološke struke."

- „Mišljenja sam da su stručni suradnici nužni zato što samo oni mogu odgovarajuće 'pokriti' naše potrebe iz područja njihove struke. Trenutno te poslove 'odrađujemo' sami."

Iz navedenih odgovora možemo zaključiti kako je trenutna brojčana situacija zaposlenih stručnih suradnika u glazbenim školama poražavajuća. Bez obzira na Državni pedagoški standard osnovnoškolskog sustava odgoja i obrazovanja i Državni pedagoški standard srednjoškolskog sustava odgoja i obrazovanja u kojima se navodi kako svaka redovita osnovna škola odnosno srednja škola koja ima do 180 učenika treba zaposliti dva stručna suradnika od kojih jedan mora biti pedagog, možemo zaključiti kako se Državni pedagoški standardi ne poštuju, a glazbene škole (i ostale umjetničke škole) koje djeluju kao samostalne jedinice ne dobivaju dovoljno potpore i podrške od strane Ministarstva znanosti i obrazovanja. Trenutna politika obrazovanja ne ide u prilog zapošljavanja stručnih suradnika u redovnim osnovnim i srednjim školama što je izrazito vidljivo na primjeru glazbenih škola. 


\section{ZAKLUČAK}

Rezultati istraživanja pokazuju kako je broj stručnih suradnika u glazbenim školama zanemariv iako možemo tvrditi da njihova uloga u odgojno-obrazovnim ustanovama nije zanemariva. Glazbene škole nositelji su obrazovnog, kulturnog i umjetničkog života u sredinama u kojima se nalaze, a osnovne i srednje glazbene škole nisu namijenjene isključivo darovitoj djeci i mladima, a razlog tome, kao što navodi Brđanović (2015), jest činjenica da učenje (kvalitetne) glazbe treba biti dostupno svima zbog osobne i društvene koristi. Prema Brđanoviću (2015) učenici glazbenih škola učenjem sviranja određenog instrumenta razvijaju radne navike, uče se timskom radu, a sudjelovanje u različitim glazbenim projektima pomaže inkluziji i socijalizaciji, no istodobno učenici glazbenih škola vrlo se često suočavaju s različitim izazovima, kao što su mogućnost neuspjeha, neuspjeh, trema, ali i sa svakodnevnim situacijama i problemima koji se javljaju kod djece i adolescenata. Jedan od izazova jest da učenici, iako izrazito daroviti u svom području odnosno temeljnom predmetu, ne postižu iste rezultate u drugim područjima kao što su teorijski glazbeni predmeti i/ili općeobrazovni predmeti. U tom slučaju uloga stručnih suradnika, kao što su pedagog i psiholog, jest provođenje individualnog i/ili grupnog savjetodavnog rada s učenicima te stvaranje optimalnih uvjeta za učenje. No, kako i na koji način to ostvariti s obzirom da glazbene škole uopće ne zapošljavaju stručne suradnike na neodređeno vrijeme? Možemo li govoriti o svojevrsnoj diskriminaciji umjetničkih odnosno glazbenih škola? Zašto učenici glazbenih škola nemaju pravo na stručnog suradnika? Zašto glazbene škole nisu istovrijedne i ravnopravne s ostalim osnovnim i srednjim školama? Vuković (2009) navodi kako se od suvremene škole očekuje kvaliteta, a prepoznatljivost svake škole nastaje kao rezultat dugogodišnjeg rada svih djelatnika. Istodobno, zahtjevi društva, politike i obrazovnog sustava sve su veći, a područja rada stručnih suradnika ostaju na teret nestručnim osobama. Možemo zaključiti kako škola koja ima cjelovit stručni tim lakše i potpunije odgovara na postavljene izazove, a istodobno pruža kvalitetu na visokoj razini svim sudionicima odgojno-obrazovnog procesa bez obzira radi li se o redovnoj osnovnoj, srednjoj ili umjetničkoj odnosno glazbenoj školi. Svaka je škola odgovorna za vlastiti razvoj, a stručni suradnici ključni su nositelji razvojne djelatnosti škole. No pitanje je kako unaprijediti kvalitetu škole ako se osnovni uvjeti za napredak ne ispunjavaju? Diskriminacija glazbenih škola u vidu broja zaposlenih stručnih suradnika mora prestati te je nužno školama pružiti stručne resurse odnosno povećati broj stručnih suradnika s ciljem razvoja i unapređenja pedagoške prakse, osuvremenjivanja nastavnog procesa, pružanja savjetodavne i terapijske pomoći učenicima, uvođenja inovacija i razvoja područja kojima se stručnih suradnici bave, a koja trenutno nisu prepoznata od strane Ministarstva znanosti i obrazovanja.

\section{LITERATURA}

Bizjak Igrec, J., Galić, M. i Fajdetić, M. (2014). Pedagoški portfolio - stručni prilozi za rad stručnih suradnika pedagoga u osnovnim i srednjim školama. Zagreb: Profil.

Brđanović, D. (2015). Glazbena darovitost i obrazovni sustav. Preuzeto s https://hrcak.srce.hr/ index.php?show=clanak\&id_clanak_jezik=225518, 15.4.2019.

Državni pedagoški standardi (2008). Zagreb: Ministarstvo znanosti, obrazovanja i športa.

Popis umjetničkih škola u Republici Hrvatskoj (2019). Ministarstvo znanosti i obrazovanja. Preuzeto s https://mzo.hr/hr/rubrike/umjetnicke-skole, 15.1.2019.

Pravilnik o tjednim radnim obvezama učitelja i stručnih suradnika u osnovnoj školi. (2014). : Ministarstvo znanosti, obrazovanja i športa. Preuzeto s https://narodne-novine.nn.hr/clanci/ sluzbeni/2014_03_34_613.html, 5.4.2019.

Vuković, N. (2009). Unapređivanje kvalitete rada školskog pedagoga. Preuzeto s https://hrcak.srce. $\mathrm{hr} /$ index.php?show=clanak\&id_clanak_jezik=123203, 17.4.2019. 


\title{
School Counselors in Music Schools in the Republic of Croatia
}

\begin{abstract}
The subject of this research is the number of employed school counselors in music primary and secondary schools in the Republic of Croatia. 38 headmasters have participated in this research, while the total number of headmasters of music schools is 52 . This survey showed the number of employed school counselors in music schools, the profil of the employed school counselors and the headmasters subjective evaluation wheather the need for this kind of experts is needed and wanted in music schools. Results indicate that the number of employed school counselors is exceptionally low, but the headmasters' assessments indicated that there is a great need for this profile of experts. It is important to emphasize that the headmasters, school counselors, teachers, parents and pupils cannot accept the current number of employed school counselors in music schools. The main objective of this research is to encourage the higher educational jurisdiction to employ school counselors in music schools for the purpose of improvement of the educational process and complete eradication of the discrimitantion which is done against music schools.
\end{abstract}

Keywords: art school, music school, school counselor, pedagogue, psychologist, expert in educational rehabilitation, librarian

\section{Mitarbeiter im pädagogischen Dienst in Musikschulen in Kroatien}

Zusammenfassung: Der Gegenstand der Forschung ist die Zahl der an den Schulen unbefristet angestellten Mitarbeiter im pädagogischen Dienst in den Musik-Grund- und Mittelschulen in der Republik Kroatien. An der Forschung nahmen 38 Schulleiter der Musikschulen teil, von insgesamt 54 selbstständigen Musik-Grund- und Mittelschulen. Befragt wurde die aktuelle Anzahl und Profil der angestellten Mitarbeiter im pädagogischen Dienst in den Musikschulen und die subjektive Einschätzung der Schulleiter, ob an den Musikschulen Bedarf nach Mitarbeitern im pädagogischen Dienst bestehe. Die Ergebnisse weisen daraufhin, dass an den Musikschulen eine unbedeutende Anzahl der Mitarbeiter im pädagogischen Dienst angestellt ist, jedoch auch, dass nach Einschätzung der Schulleiter großer Bedarf an pädagogischen Mitarbeitern unterschiedlicher Profile besteht, in Grundschulen und Mittelschulen gleichermaßen. Es ist sehr wichtig zu betonen, dass sich die Schulleiter, die Mitarbeiter im pädagogischen Dienst, die Schüler und die Lehrer mit dem bestehenden Zustand nicht zufriedengeben sollten, trotz der momentanen Situation. Das Ziel dieser Forschung ist es, die hohen Bildungsinstanzen zum Anstellen der Mitarbeiter im pädagogischen Dienst anzuspornen, mit dem Ziel der Förderung des Erziehungs- und Bildungsprozesses, der Hilfeleistung und der Unterstützung der Schüler in den Musik-Grund- und Mittelschulen, Einhalten des staatlichen pädagogischen Standards und gründlicher Bekämpfung der Diskriminierung, die beim unbefristeten Anstellen der Mitarbeiter im pädagogischen Dienst ausgeübt wird.

Schlüsselwörter: Kunstschule, Musikschule, Mitarbeiter im pädagogischen Dienst, Pädagoge/in, Psychologe/in, Rehabilitationswissenschaftler/in, Bibliothekar/in 